\title{
Deixis in Modern Linguistics and Outside
}

\author{
Ardita Dylgjeri \\ "Aleksandër Xhuvani" University of Elbasan, Albania \\ E-mail: arditadylgjeri@live.com \\ Ledia Kazazi \\ "Aleksandër Xhuvani" University of Elbasan, Albania \\ E-mail: lediakazazi@live.com
}

\section{Doi:10.5901/ajis.2012.v2n4p87}

\begin{abstract}
:
In many ways modern linguistics is one of the most remarkable and successful scientific innovations of the twentieth century. It is related only to linguistic studies, but to other disciplines as well such as: philosophy, cognitive psychology, anthropology and literary studies. And to the present day modern linguistics is held up as a model of scientific innovation to other disciplines in the humanities. Pragmatics, a subfield of linguistics developed in the late 1970s, studies how people comprehend and produce a communicative act or speech act in a concrete speech situation. It distinguishes two intents or meanings in each utterance or communicative act of verbal communication. One is the informative intent or the sentence meaning, and the other the communicative intent or speaker meaning (Sperber and Wilson, 1986). The ability to comprehend and produce a communicative act is referred to as pragmatic competence which often includes one's knowledge about the social distance, social status between the speakers involved, the cultural knowledge such as politeness, and the linguistic knowledge explicit and implicit. Deixis belongs within the domain of pragmatics because it directly concerns the relationship between the structure of language and the context in which they are used. (Levinson 83, p. 55). It is often and best described as "verbal pointing", that is to say pointing by means of language. The linguistic forms of this pointing are called deictic expressions, deictic markers or deictic words; they are also sometimes called indexicals. Deictic expressions fall into three categories: Person deixis (you, us etc), spatial deixis (here, there), and temporal deixis (now, then).
\end{abstract}

Key words: deixis, pragmatics, spatial, temporal, personal.

\section{What is deixis?}

"The pointing or specifying function of some words (as definite articles and demonstrative pronouns) whose denotation changes from one discourse to another" (http://www.merriam-webster.com/dictionary/deixis)

The word deictic has its roots in the Greek word 'deiktikos', meaning 'able to show'; which comes from the word deiktos; which is a verbal of the word deiknynai, meaning to show. A related word is deixis, used in pragmatics and linguistics where it refers to a process whereby either words or expressions are seen to rely utterly on context. (http://dictionary.reference.com/browse/pragmatics?s=t)

In modern linguistic studies as according to (Levinson S. C., Cognitive anthropology , 1995, p. 10) it means as follows:

"Deixis is an important field studied in pragmatics, semantics and linguistics. Deixis refers to the phenomenon wherein understanding the meaning of certain words and phrases in an utterance requires contextual information. Words or phrases that require contextual information to convey any meaning are deictic";and furthermore "Deixis concerns the ways in which languages encode ... features of the context of utterance ... 
and thus also concerns ways in which the interpretation of utterance/es depends on the analysis of that context of utterance." (Levinson S. C., 1995, p. 12).

Deixis does not only have the function of a grammatical constituent, but it has the duty to point out the different meaning the words have even in cases they are used in the same way in different situations. Traditional grammar does not have the ability or the resources to show the difference in such cases. The timing, place, message bearers have their importance in the communicating process. On the other hand modern linguistics has a different approach. Pragmatics, analyzing the words and the language terms in the situational terms, related to the context cultural, temporal, spatial, social and so on of the participants in the communicating process (dicionary reference), makes it easier to have a better view of the thought that is being transmitted.

The language is not a mere juncture of words. Each and one word can and cannot be in the same time a deixis (Levinson S. C., 1995, p. 10). If the language did not have a pragmatic approach toward itself it could not evolve, transform itself, adapt into a modern or tomorrow's form.

\section{The place of deixis in pragmatics and semantics}

Is deixis to be considered a pragmatic's constituent? Absolutely yes but one should better differ if is taking a linguistic overview or a philosophical one. The linguistic studies do not differ if the sentence if the sentence is true or false. This is a job that philolosophical pragmatics can do, by referring to a word with deictic functions as an indexical (Lycan, 2000, pp. 165-168). Not only this, the indexical has a wider field of choosing words and interpreting words as having a deictic function. Deixis helps semantics to better analyze the context of an utterance.

Deixis is reference by means of an expression whose interpretation is relative to the (usually) extra linguistic context of the utterance, such as:

- who is speaking

- the time or place of speaking

- the gestures of the speaker, or

- the current location in the discourse.

Deixis is "the single most obvious way in which the relationship between language and context is reflected" (Levinson S. C., Pragmatics., 1983, p. 53), constituting "key points of juncture between grammar and context" (Hanks, 1992, p. 47)

Deixis concerns the ways in which languages express features of the context of utterance or speech event in a different way. It concerns ways in which the interpretation of utterance depends on the analysis of that context of utterance. Deictic information is important for the interpretation of utterance.

If semantics is taken to include all conventional aspects of meaning, then perhaps most deictic phenomena are probably considered semantic in Levinson's point of view (1995, p. 34), but deixis belongs to the domain of pragmatics, because it directly concerns the relationship between the structure of languages and the contexts in which they are used.

As we said above, deixis belongs in the domain of pragmatics. In this domain according to Levinson (1995, p. 34), deixis is collectively the orientational features of human languages to have reference to specific points in time, space, and the speaking event between interlocutors. A word that depends on deictic clues is called a deictic or a deictic word. Deictic words are bound to a context, either a linguistic or extralinguistic context for their interpretation.

And also Levinson (1995, p. 35) said that, in linguistics, deixis refers to the phenomenon wherein understanding the meaning of certain words and phrases in an utterance requires contextual information. Words are deictic if their semantic meaning is fixed but their denotational meaning varies depending on time and/or place. Words or phrases that require contextual information to convey any meaning - for example, English pronouns are deictic. Deixis is closely related to both indexicality and anaphora. But if 
indexicality is often referred to lexemes in a philosophic point of view, the study of deictic words is strictly linguistic. Also the indexicalities appear to implicate a wider ways of transmitting the message and the kind of the signs used: In conversation (Levinson S. C., 1995, p. 36), interpretation of indexical expressions may in part depend on a variety of paralinguistic and non-linguistic features, such as hand gestures and the shared experiences of the participants (Lycan, 2000, p. 168).

In another point of view deictic expressions, place and time adverbs, and pronouns are just particularly clear illustrations of a general fact about situated language. (Suchman, 1990, p. 21)

Levinson (1995, p. 32) thinks that it is helpful to distinguish between two usages of deixis, gestural and symbolic, as well as non-deictic usages of frequently deictic words. Gestural deixis refers, broadly, to deictic expressions whose understanding requires some sort of audio-visual information. A simple example is when an object is pointed at and referred to as "this" or "that". However, the category can include other types of information than pointing, such as direction of gaze, tone of voice, and so on. Symbolic usage, by contrast, requires generally only basic spatio- temporal knowledge of the utterance. So, in the examples below:

"I broke that pot."

requires being able to see which pot is being shown at, whereas

"l love this song."

requires only to be listening the song in the same moment with the interlocutor. In a similar vein,

"I loved listening to this song over and over"

is a non-deictic usage of "this", which does not reference anything specific.

Deixis is clearly tied to the speaker's context, according to Huddleston (2006, p. 21) the most basic distinction being between near the speaker (proximal) and away from the speaker (distal). Proximal deictic expressions include this, here and now. Distal deictic expressions include that, there and then. Proximal expressions are generally interpreted in relation to the speaker's location or deictic centre. For example now is taken to mean some point or period in time that matches the time of the speaker's utterance.

The term deictic is applied to a word which specifies an identity or a temporal or a spatial location from the perception of a speaker or a listener in the circumstance in which the communication takes place. It could mean relating to or the distinctiveness of a word, the reference of which is dependent on the conditions of its use. Another meaning of the word deictic is directly showing or pointing out. For instance, the terms 'those', 'that', as well as 'this' have a deictic function.

Levinson (1995, p. 39) points out that there are five types of deixis: spatial, temporal, person, social and discourse. The first three are more common than the last two.

The phenomenon of deixis has been of considerable interest to philosophers, linguists, and psychologists. It raises a great number of puzzles about the proper way to think about the semantics of natural languages, and about the relation of semantics and pragmatics. It also reminds us that natural languages have evolved for primary use in face-to-face interaction, and are designed in important ways to exploit that circum- stance. As people take turns talking, the referents of $I$, you, here, there, this, that, etc. systematically switch too; children find this quite hard to learn (Wales 1986, p. 57), but the penalties of such a system far outweigh the advantages of, e.g., substituting unique proper names (if indeed such a system could even in principle operate in a full language, see (Lyons 1977:639ff).

When humans communicate, much of what goes on is not simply about conveying information to others. One problem regarding the way in which semantics describes meaning is that anything that goes beyond the content of the linguistic sign itself is outside the scope of description. Social and affective meaning are not covered by semantics (which focuses on conventional/conceptual meaning only), but 
virtually any real-life communicative situation contains countless signs which are used to express something about the speakers and their social relationships.

"We will not stop in our way towards Europe." in this case, in a special way in Albania, it does not refer to the continent and definitely does not refer to any other thing but European Union, a political entity not a spatial one. The interpretation of what meanings the speaker wanted to convey using particular words is often influenced by factors such as the listeners' assumptions or the context. In pragmatics two types of context can be differentiated: linguistic context and physical context. Linguistic context, sometimes called co-text is the set of words that surround the lexical item in question in the same phrase, or sentence. The physical context is the location of a given word, the situation in which it is used, as well as timing, all of which aid proper understating of the words.

The context of an utterance is crucial in the interpretation of certain words and in the complete convey of the meaning. Words such as here and there, this or that, now and then, yesterday, today or tomorrow as well as pronouns such as you, me, she, him, it them can be ambiguous if we are not aware of the physical context of the speaker. Certain circumstances determine the meaning of some English sentences. In order to understand these sentences we must know who the speaker is, who is he/she speaking to, about whom, where and when. This knowledge about the context is identified as non-linguistic knowledge because the knowledge of these circumstances does not belong within the framework of the general knowledge about a language. (Saeed, 2003 p.23)

For example: Bring it this evening because she will be here by then.

Out of context this would be quite a vague sentence. Some of the expressions present here rely on the knowledge of context in order to be interpreted. Expressions such as this evening and here can only be understood in the terms of the speaker's intended meaning. These are known to be deictic expressions, as mentioned above, from the classical Greek word deiknymi (to show, to point out) or deixis. Deixis means "pointing" by means of language.

\section{Types of deixis}

According to Bühler (Buhler, 2011, p. 67) there is a deictic centre that consists of $I$, Here and Now. As a result there are three main categories of deixis:

1. Person deixis, used to point to objects (it, these, those books) and people (her, him, them, those students)

2. Spatial deixis, used to point to a location (here, there, close to)

3. Temporal deixis, used to point to a time (now, then, next week, last month) In order to interpret all these deictic expressions we must know which person, time and place the speaker has in mind. There is a great difference on what is close to the speaker (this, here, now) and what is distant (that, there, then). We can also realize whether there is a movement away from the speaker (go) or there is a movement towards the speaker (come). If somebody is moving towards you, you say: He is coming! If somebody is moving away from you, you say: He is going!

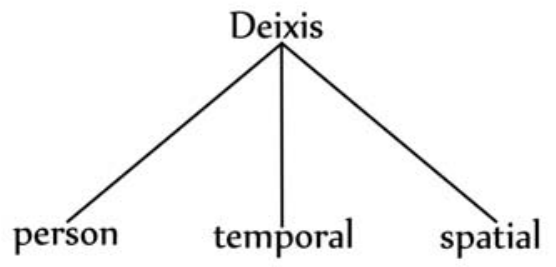




\subsection{Person Deixis}

Person deixis deals with the correct identification of the grammatical persons used to refer to the speaker and the addressee. Examples of person deixis may consist of:

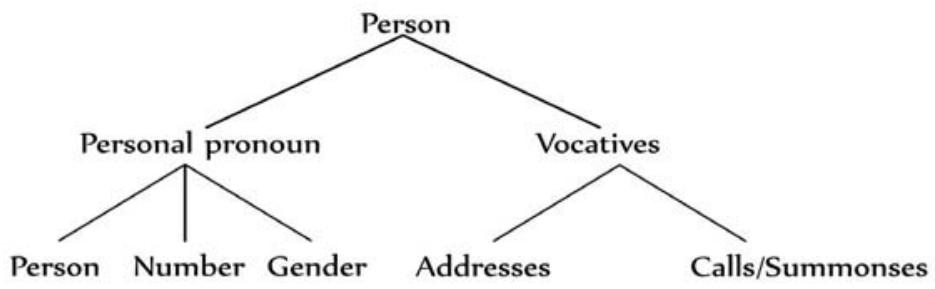

\section{- Personal pronouns.}

In every language there is a first-person pronoun and a second-person pronoun. The first person is used by the speaker as a means of referring to him/herself and the second-person is used to refer to the addressee or the audience. In many languages (not all of them) we notice the presence of the third-person pronoun, which is used to refer to entities different from the speaker and the addressee. Since these pronouns are not directly involved in the utterance they are not considered deictic.

Ex: l've got a nice place here, he said, his eyes flashing about restlessly.

I live at West Egg.

It'll show you how l've gotten to feel about- things. (Fitzgerald, p. 20)

Boys, was someone you felt you knew - and wanted to know better.

(Stanford, 2013)

The number system differs from language to language. The most commonly found systems make a distinction between the Singular and the Plural or sometimes between the Singular-Dual-Plural. Those pronouns that must be carefully considered are the first person plurals. As we all know these pronouns refer to more than one entity, but what we might not know or be sure about is whether the speaker includes or excludes the addressee. This is the case with English. We do not know whether the pronoun "we" includes the addressee or not.

Ex: We drove over to Fifth Avenue, so warm and soft, almost pastoral, on the summer Sunday afternoon that I wouldn't have been surprised to see a great flock of white sheep turn the corner.

We gave her spirits if ammonia and put ice on her forehead and hooked her back into her dress and half an hour later when we walked out of the room the pearls were around her neck and the incident was over. (Fitzgerald, p. 70)

Besides, we already suffered the consequences of a "sequester" —in other words, we are condemned by a series of macroeconomic indices that we (as Europeans) built. (Emanuele, 2013)

\section{- Gender}

In many languages pronouns are also marked for gender. As far as English is concerned there is gender distinction only in the third person singular "he/she". In other languages gender can be realized in first and second pronouns too. 
Ex: She's said to be very beautiful by people who ought to know.

He was a blonde, spiritless man, anemic, and faintly handsome. (Fitzgerald, p. 28)

One imagines he was perennially among the favourites in those tasteful New Year betting markets about the next celebrity demise. (Mathew, 2013)

\section{- Vocatives}

Vocatives are noun phrases used to address someone. They are not an argument of the predicate.

Ex: Mary, you have to eat the toast.

\subsection{Spatial deixis}

In every language the speaker sets up a frame of reference around himself. So there is always a division of space around him and of course there is a division of time relative to his utterance.

The most frequent words that carry deictic characteristics are the demonstrative pronouns, respectively this/ that and these/ those. This kind of deixis is known as spatial or space deixis. Other expressions that belong to this category are the adverbs here/ there and some uses of the prepositions in/ on (in the classroom, on the chair). Spatial deixis also implies some proximal or distal interpretations. For instance, here/ this/ these locate something near to the speaker. Anyway we still cannot denote the complete meaning of the utterance because here might refer to every kind of area, being this a room, a city or a country. On the other hand there/that/those locate something far from the speaker.
Ex: I've got a nice place here, he said, his eyes flashing about restlessly.
She's going to spend lots of week-ends out here this summer.
'Hold on', I said, 'I have to leave you here'. (Fitzgerald, p. 31)
It is a great honor and privilege to address today this distinguished audience gathered here to discuss issues of priority importance, such as the security policies. (European times)

As seen from the examples demonstratives are used to denote certain items that are positioned either close or distant to the speaker. However according to Huddleston and Pullim (2006, p. 150) the choice of a demonstrative does not always depend on the position of the speaker. According to them the demonstratives can also refer "to properties of such objects or to actions taking place or other abstract features of the situation of utterance". In this case spatial deixis is used as a form of orientation in a discourse and therefore it is called discourse or textual deixis. Thus in the following examples we will witness that this and that do not necessarily place a statement closer or further from the speaker. That in this case points to a statement previously made by the speaker.

Ex: At this point Miss Baker said "Absolutely!"- it was the first word she uttered since I came in the room. (Fitzgerald, p. 13)

Back in the spotlight this week after a bizzare defence of London Mayor Boris Johnson in 'The Spectator', Darius Guppy still courts controversy. (Stanford, 2013)

This is a kind of metaphorical shift from the concrete framework of place into the more abstract framework of time.

In addition, there are some kinds of spatial adverbs that locate objects or items in different positions relative to the speaker. Sometimes the speaker itself cannot determine whether the item is close to him or far from him.

Ex: Where have I left it? Here or there? 


\subsection{Temporal deixis}

As witnessed in the previous examples there is a general trend that that notions of space develop into notions of time. (Charles F, 2009) This explains why some spatial prepositions like in and on have developed into notions of time.

Thus in expressions like in the evening, on time, at midnight the prepositions in/on/at are markers of time or temporal deixis. In English, temporal deixis is expressed by adverbs of time and tense markers on the verb. There are two tenses in English that are morphologically marked on verbs. They are the present and the past. To refer to events taking place in the future English uses modal verbs, will or shall and the phrasal modal be going to.

\section{Ex: It will show you how l've gotten to feel about things. Jordan is going to play in the tournament tomorrow. I am going to fix everything, just the way it was before. Shall we all go in my car? (Fitzgerald, p. 128)}

But sooner rather than later it also will have to deal with the reality of everyday life, which is a hard political exercise. (Guido, 2013).

Another means of expressing the future is using a present tense verb but attaching an adverb of time to indicate the future.

\section{Ex: I leave this country tomorrow. They return next month.}

The usage of the modal verb shall is mostly a characteristic of British English, while in American English they prefer will. Wherever a present tense verb is used with future reference an adverb of time is needed. Being markers of the future, adverbs of time can also be used with the modals shall, will and be going to.

\section{Ex: Jordan is going to play in the tournament tomorrow. (Fitzgerald, p. 21)}

The English Past Tense points at events that occurred at a specific time in the past and finished at a specific time in the past. The following sentences provide examples of completed events.

Ex: Though I was curious to see her, I had no desire to meet her- but I did.

His voice faded off and Tom glanced impatiently around the garage.

Then I heard footsteps on a stairs and in a moment the thick figure of a woman blocked out the light from the office $\overline{\text { door. }}$ (Fitzgerald, p. 28)

By all accounts, Richard Griffiths more than made up for the silence in which he grew up. A man of legendary loquacity with his friends, professionally he pulled off the fiendishly difficult trick of mingling the fatman jollity and unforced warmth with a beguilingly understated sense of pathos and vulnerability. (Mathew, 2013)

The Present Tense in English is a bit more complicated. One of its uses is to mark a period of time that finishes immediately after the utterance. In the following sentence the event is over immediately after the utterance.

\section{Ex: Here is another thing I always carry. (Fitzgerald, p. 72)}

Another usage of the present simple is the expression of events occurring on a regular basis. 
Ex: How do you get to West village?

He reads deep books with long words in them. (Fitzgerald, p. 16)

Due to these different shifts of the present in English, different grammarians including Quirk argue that semantically English has a past tense and a non past tense and it doesn't have a present tense. It is considered that in examples similar to the following the verb marker indicates aspect and not tense because it indicates a habitual action and not a point in time.

Ex: Occasionally a line of grey cars crawls along an invisible track... (Fitzgerald, p. 26)

Since aspect views time as continuous or habitual and does not point a specific time, it is not considered deictic. Anyway, the time and aspect in English may sometimes be very blurry: thus the Past Simple and the Present Perfect can substitute each other and there is little temporal difference among the two.

English has two aspects: the perfect and the continuous. These two work together to produce several temporal sequences. The perfect is formed with the verb have in the present or past in conjunction with a participle. For instance the Present Perfect indicates an event that started in the past but continues to the present (and sometimes to the future). In the following example the verb has arrived indicates that the progress mentioned in the sentence started at seven o'clock and has continued to the present.

Ex: By seven o'clock the orchestra has arrived.... (Fitzgerald, p. 44)

Sequester is the name that has been assigned to the automatic cuts in public spending imposed on the federal budget. (Emanuele, 2013)

The Past Perfect is also used to express an event that has started in the past, but the event finished before the beginning of another event.

Ex: Though here and there was a face I had noticed on the commuting train. (Fitzgerald, p. 46)

... - he said that he had been made lifetime dictator. (Mathew, 2013)

\section{Other deictic categories}

Even though the above mentioned are the most obvious categories of deixis, according to some modern linguists such as Fillmore and Lyons there two other types of deixis worth studying. (Lyons, 1977, p. 34)

\subsection{Discourse deixis}

Mostly referred to as text deixis, discourse deixis refers to the expressions used in a discourse. These expressions include the utterance itself.

Ex: This is an unusual party. (Fitzgerald, p. 55)

"It sounded like this: whoosh". (Stanford, 2013)

"this" refers to an upcoming portion of the discourse, and in

Ex: That was comprehensible. (Fitzgerald, p. 44)

"that" refers to a prior portion of the discourse.

-'You are wrong'. That's exactly what she said" (Mathew, 2013) 
This type of deictic expressions can sometimes be confused with the anaphora. Anaphora is used to refer to something previously mentioned.

Ex: One of the girls in yellow was playing the piano........ She had drunk a quantity of champagne.... (Fitzgerald, p. 56)

However, according to Lyons, certain expressions can be both deictic and anaphoric at the same time. (Lyons 1977, p, 34 )

Ex: I live at West Egg. -Really? I like it there. (here)

Here and there are anaphoric expressions since they refer to a referent previously mentioned, West Egg. However, they are deictic because the usage of here or there indicates the current location of the speaker.

In order to distinguish the two possibilities we must be careful to define what the expression refers to. It has to be anaphoric if it refers to a prior referent, already mentioned within the utterance and it is discourse deictic when it refers to a piece of discourse.

\subsection{Social deixis}

This kind of deixis is related to the social information encoded within an utterance. According to Levinson (Levinson S. C., 1979, p. 67) social deixis is: those aspects of language structure that are anchored to the social identities of participants (including bystanders) in the speech event, or to relations between them, or to relations between them and other referents.

There are two examples of social deixis:

\section{- $\quad$ The TN form}

It stands for the Latin words "tu" (singular second person pronoun), which is used to address to a speaker in an informal and relaxed way and "vos" (plural second person pronoun), which is used in a more formal or polite context. But even in English

$$
\text { Ex: I tell Thee what Anthonio, I love } \underline{\text { Thee, }} \text {, and it is my love that speaks }
$$

To furnish Thee to Belmont, to fair Portia. (Shakespeare Navigators, 2011)

Thee is an archaic pronoun (http://dictionary.reference.com/browse/thee) derived by thou, nowadays used only in ecclesiastic functions. However thee in Elizabethan English has not only been widely used but it has the same role as Vous in French, or Lei in Italian, or Sie in German

\section{- Honorifics}

Honorifics are similar to the T/V distinction, however they are more complex. They involve the usage of particular lexemes in order to show the actual status of the interactants. For example the meaning of the phrase "The President" may be determined by the country in which it is spoken. Since there are many presidents around the world, the location of the speaker provides extra information that allows the president to be identified. 


\section{Conclusions}

Deixis is a linguistic notion within the domain of pragmatics. Pragmatics studies the way individuals produce and comprehend a communicative act of speech in a concrete speech situation. The ability to produce and comprehend these acts requires a special knowledge of context. That's why deixis is a crucial element of pragmatics. It is closely related to the context of an utterance and the structure of language. As seen from the above examples deictic elements are present not only in literary texts but in other pragmatic texts such as newspaper articles or even everyday speech. There are two main divisions of deictic elements. According to traditional linguists there are three main types of deixis: Person deixis, Temporal deixis and Spatial deixis. Modern linguists recognize two extra divisions. They are: Social deixis and Discourse deixis.

\section{References}

Buhler, K. (2011). Theory of Language. Amsterdam/ Philadelphia: John Benjamins Publishing Company .

Charles F, M. (2009). Introducing English linguistics. Cambridge: Cambridge University press.

dicionary reference. (n.d.). Retrieved February 28, 2013, from http://dictionary.reference.com/browse/pragmatics?s=t

dictionary reference. (n.d.). Retrieved March 15, 2013, from dictionary reference: http://dictionary.reference.com/browse/thee

Emanuele, P. V. (2013, March 09). II sole 24 ore. Retrieved March 13, 2013, from II sole 24 ore: http://www.llsole24ore.com /art/english -version/2013-03-09/desequestering-economy-italys-035150.shtml?uuid=AbVtYNcH

European times. (n.d.). Retrieved March 1, 2013, from http://www.worldsecuritynetwork.com/NATO/Munich-Conference-onSecurity-Policy/Sali-Berisha-Albanian-President/

Fitzgerald, F. S. (1993) The great Gatsby. Wordsworth Edition Itd, Hertfordshire:

Guido, G. (2013, March 9). il sole 24 ore. Retrieved March 13, 2013, from II sole 24 ore: http://www.ilsole24ore.com/art/englishversion/2013-03-12/clueless-country-perilous-situation-023859.shtml?uuid=AbUrH9cH

Hanks, W. F. (1992). The Indexical Ground of Deictic Reference. In Rethinking Context, Language as an Interactive Phenomenon. (A. D. Goodwin, Ed.) Cambridge University Press.

Huddleston Rodney, P. G. (2006). A Student's Introduction to English Grammar. Cambridge Univ. Press.

Levinson, S. C. (1995). Cognitive anthropology . In Handbook of Pragmatics, 10,12.

Levinson, S. C. (1979). Pragmatics and social deixis in Proceedings of the Fifth Annual Meeting of the Berkeley Linguistic Society. Berkeley: Berkeley Linguistics Society.

Levinson, S. C. (1983). Pragmatics. Cambridge: Cambridge University Press.

Lycan, W. G. (2000). PHILOSOPHY OF LANGUAGE A contemporary introduction. New York: Routledge.

Lyons, J. (1977). Deixis, space and time" in Semantics, Vol. 2. Cambridge University Press.

Mathew, N. (2013, March 29). Daily Telegraph. Retrieved March 29, 2013, from Daily Telegraph: http://www.telegraph.co.uk/culture/film/9961489/Richard-Griffiths-the-greatest-of-the-history-boys.html

Saeed, J. (2003). Semantics, second edition. Cornwell: Blackwell Publishing.

Shakespear, W. (2011, March 31). Shakespeare Navigators. Retrieved March 2013, 13, from http://www.shakespearenavigators.com/merchant: http://www.shakespeare-navigators.com/merchant/MerchantText11.html

Stanford, P. (2013, March 29). Daily telegraph. Retrieved March 29, 2013, from http://www.telegraph.co.uk/news/celebritynews 19961473/Darius-Guppy-That-element-of-madness-was-always-there.html

Suchman, L. A. (1990). What Is Human--Machine Interaction? (W. Z. Scott P. Robertson, Ed.) Cognition, Computing, and Cooperation. 